\title{
WOMEN PERFORMING REPETITIVE WORK: IS THERE A DIFFERENCE IN THE PREVALENCE OF SHOULDER PAIN AND PATHOLOGY IN SUPERMARKET CASHIERS COMPARED TO THE GENERAL FEMALE POPULATION?
}

VALERIO SANSONE ${ }^{1,2}$, CRISTINA BONORA ${ }^{2}$, PAOLA BORIA ${ }^{3}$, and ROBERTO MERONI ${ }^{4}$

${ }^{1}$ University of Milan, Milan, Italy

Orthopaedic Department

${ }^{2}$ Galeazzi Orthopaedic Institite IRCCS, Milan, Italy

Orthopaedic Department

${ }^{3}$ Occupational medicine - private practice, Milan, Italy

${ }^{4}$ University of Milano-Bicocca, Milan, Italy

Department of Surgery and Interdisciplinary Medicine, Program in Physical Therapy

\begin{abstract}
Objectives: Shoulder disorders in the occupational environment have been widely studied, but the quality of research and methodology applied vary. Little has been done to ascertain whether shoulder pain in female repetitive workers is due to any verifiable pathology, or to compare findings with the general population. Therefore, we decided to evaluate the prevalence of self-reported shoulder pain in a group of female supermarket cashiers and in the general female population using a standardized questionnaire. Shoulder pain prevalence was then compared to imaging findings in order to assess specific and non-specific pain prevalence. Material and Methods: 196 cashiers and 302 controls filled in a standardized shoulder questionnaire and underwent an imaging examination of a shoulder. Results: The prevalence of shoulder pain was significantly higher in the group of cashiers (46.4\%) than in the general population $(25.5 \%)(\mathrm{OR}=1.821$; $95 \% \mathrm{CI}$ : $1.426-2.325)$. Specific pain prevalence was higher among the controls $(19.5 \%)$ than among the cashiers $(13.2 \%)$. Conclusions: The more frequent reports of shoulder pain in the supermarket cashiers are not correlated with a higher prevalence of imaging abnormalities. The causes of these more frequent complaints should be probably sought in the psycho-social and occupational environment.
\end{abstract}

Key words:

Female working-age population, Non-specific shoulder pain, Prevalence, Repetitive work, Supermarket cashiers, Ultrasonography

Received: November 25, 2013. Accepted: May 16, 2014.

Corresponding author: V. Sansone, Istituto Ortopedico Galeazzi IRCCS, via Riccardo Galeazzi 4, 20161 Milano, Italy (e-mail: valerio.sansone@unimi.it). 


\section{INTRODUCTION}

Musculoskeletal disorders (MSDs) is a broad term which encompasses a range of inflammatory and degenerative conditions affecting limbs and spine. They range from non-specific pain syndromes that cannot be attributed to any known pathology, to clearly defined, specific disorders. MSDs constitute one of the most common and costly public health issues in Western societies and, more specifically, MSDs of the upper limb are important causes of morbidity and sickness absence [1,2]. In particular, shoulder problems are very common in Europe and North America [3-7]. In the general population, the reported prevalence of shoulder complaints ranges from $6.9-26 \%$ for point prevalence, $18.6-31 \%$ for 1-month prevalence, and $4.7-46.7 \%$ for 1-year prevalence [6]. In the Netherlands, the 1-year period prevalence was estimated at $30.3 \%$, with associated limitations to daily life and frequent sick leave [8].

In the working population, shoulder disorders and complaints constitute an important and costly health problem. Shoulder pain results in millions of working days being lost per year [9] and costly insurance compensation claims [10]. Although shoulder complaints in the working population have been widely studied, accurate and comparable data on the incidence and prevalence are hard to obtain, and official statistics are difficult to compare across various countries. Moreover, interpretation of the findings is limited by heterogeneity of case definitions, assessment of exposure and the design of longitudinal studies. In a review of shoulder pain in occupational settings performed by van der Windt et al., the authors have found substantial heterogeneity across the studies with regard to the study setting, exposures measured, methods of exposure assessment, statistical analysis and data presentation [11]. This multiplicity hinders sensible statistical pooling of the results.

Gender differences constitute another major complicating factor in the assessment of shoulder disorders. Disparities in the prevalence of musculoskeletal complaints, with a significantly higher prevalence in women, are supported by several studies and are more clearly defined for neck and upperextremity complaints than for back complaints [4,12-19]. Gender discrepancy has been observed both in the general population $[4,8,20,21]$ and in primary care $[22,23]$.

In the working population, the gender difference for upper-limb MSDs is confirmed, although relatively little research has been focused specifically on upper limb complaints in female workers. Indeed, in their 2010 report, the European Agency for Safety and Health at Work called for more research into upper limb disorders occurring in higher risks groups such as women, younger and temporary workers [24]. The shoulder is reported as one of the most common sites of pain amongst female workers, especially when repetitive actions are performed [21,25-29]. However, again there is lack of reliable data, even on the real prevalence of shoulder disorders in women whose occupation requires performance of repetitive tasks.

A further hindrance to accurate analysis of the burden of shoulder MSDs is caused by the diagnostic methods used in the collection of data. The majority of the information reported in the existing studies has been gathered using questionnaires, which consider only subjective symptoms, according to a considerable variety of case definitions [9]. Very few studies indeed have evaluated pain as stated by objective measures, using methodologies capable of revealing the range of most common musculoskeletal disorders, such as radiological examination.

A scientifically valid diagnosis is of particular importance in the light of the now well-recognized and accepted evidence of 2 coexisting types of shoulder pain: the specific and nonspecific pain [7,30]. The different nature of these 2 conditions should be taken into account when planning treatment and prevention strategies, as they may be completely different. Specific pain is due to a well-defined shoulder disorder, clinically and/or radiographically diagnosed. Non-specific pain can be defined as the presence of pain without physical signs or any recognizable underlying pathology [30]. Although a very common complaint, little is known about its aetiology [30-32]. 
Based on these considerations, this cross-sectional, blinded, controlled study aimed at shedding light on the shoulder pain issue in female workers. The primary goal of the study was to evaluate the prevalence of shoulder pain in a group of female workers who performed a repetitive job, compared to a group of female working-age subjects selected at random from the general population. A secondary purpose was to investigate whether the reported pain was correlated with any underlying shoulder abnormality on imaging. To our knowledge, this is the only study that compares reported shoulder pain with imaging findings, in a group of female workers.

\section{MATERIAL AND METHODS}

Between November 2011 and April 2012, all the female cashiers from 3 supermarkets in the same province of northern Italy were requested to participate in our study. One hundred ninety six cashiers agreed to take part in it, whilst 24 were unable or refused to participate. The mean duration of employment as a supermarket cashier was $11.49 \pm 6.93$ years (min. 6 months, max 31.25 years). A control group, consisting of 302 female subjects from the general population, was recruited from the customers of the supermarkets where the cashiers worked. A prepaid gift card was given to reduce the selection-bias: a free ultrasonographical examination and the amount of time needed to fill in the questionnaires could have been selective factors for subjects with a pre-existing pathology.

Exclusion criteria included: presence of evident or previously diagnosed major pathologies such as rheumaticlinked conditions, brachial plexus palsy, tumors, or major trauma (fractures of the upper humerus or glenoid and recurrent gleno-humeral dislocations), and presence of specific risk factors such as heavy and/or repetitive work. Repetitive work was defined as work that involved continuous repetitive hand or arm movements (e.g., data entry, packing, letter sorting, shop cashier, machine feeding, sewing, etc.) [33]. All the subjects signed an informed consent document before commencement of the study.

The study was divided into 2 parts. Firstly, each subject responded to a questionnaire that focused on pain of the upper limb and was based on the criteria of the Nordic Musculoskeletal Questionnaire [34]. To ensure that each subject fully understood the questions, the questionnaire was administered by an orthopaedic specialist. The questionnaire asked whether the subject had pain in their shoulders, and if pain was present, the characteristics of the symptoms were requested. In order to capture chronic, acute and continuous symptoms, in our questionnaire "pain" was defined as being in pain for at least 1 day a month, or for at least 7 consecutive days, in the past year. A positive response to either of these possibilities was defined as a "symptomatic shoulder." A negative response was deemed an "asymptomatic shoulder."

The second part of the study consisted of a static and dynamic ultrasound (US) assessment of both shoulders. This was performed by a blinded radiologist with 20 years of experience in musculoskeletal diseases and ultrasound examination. The equipment included a very high resolution linear tranducer (Logiq E9 with a $15 \mathrm{MHz}$ matrix probe, G.E Healthcare, Milwaukee, WI, USA). The radiologist, unaware of the symptoms or medical history of the subject, evaluated both shoulders. The purpose of the examination was to assess the presence of abnormalities affecting anatomic structures, rather than to investigate the specific characteristics and presentation of particular pathologies. After the ultrasound examination, the radiologist filled in a data sheet based on a binary criterion: whether the findings for each anatomical structure were normal or abnormal. A tendon was considered abnormal when 1 or more of the following features were observed: thickening or thinning of the structure, foci of increased and/or reduced echogenicity, significant calcifications, partial or full-thickness discontinuity [35].

Abnormal findings during the dynamic assessment were: biceps tendon instability within the bicipital groove; 
subscapularis bunching against coracoid; supraspinatus bunching against the acromion or coraco-acromial ligament. If the radiologist had any doubts concerning the ultrasound findings, the subject underwent a magnetic resonance imaging (MRI) examination (Intera 1.5T, Philips Healthcare, Eindhoven, Netherlands). The data sheet was then compiled according to the MRI results.

\section{Ethics}

The study was performed according to the ethical standards of the local Institutional Review Board and to the Helsinki Declaration of 1975, as revised in 1983.

\section{Statistical analysis}

Descriptive statistics were used to describe the study samples, and independent Student's t-test was used in order to compare the means of the 2 independent samples. Odds ratios and prevalence ratios with $95 \%$ confidence interval were used for $2 \times 2$ contingency tables. The $\mathrm{Chi}^{2}$ statistic was used to investigate whether distributions of categorical variables differed from one another. For all analyses SPSS Version 21 (version 21; IBM, Armonk, NY) was used.

\section{RESULTS}

The age range for the whole cohort of 498 subjects was from $20-55$ years, with a mean age of $38.11 \pm 8.64$ years. The right arm was dominant in 465 subjects (93.4\%), and the left was dominant in the remaining $33(6.6 \%)$. In the cashiers group, $92.9 \%$ (182 subjects) were right arm dominant, compared to $93.7 \%$ (283 subjects) in the control group. There was no statistical difference between the anthropometric characteristics of the 2 groups (see Table 1).

\section{Self-reported pain}

According to the findings from the questionnaire, $46.4 \%$ of the cashiers (91 subjects) reported shoulder pain, as opposed to $25.5 \%$ (77 subjects) in the control group $(\mathrm{OR}=1.821 ; 95 \%$ CI: $1.426-2.325)$. This significantly higher prevalence of symptomatic shoulders in the cashiers versus controls was observed in both the dominant and non-dominant limb (see Tables 2 and 3).

\section{Correlation between the age \\ and reported presence of shoulder pain}

The distribution of shoulder symptoms according to age for the 2 groups, for both the dominant and the non-dominant arm, is presented in Table 4. Both for the cashiers and for the control group there was a higher prevalence of symptomatic subjects in the older age groups, with the symptomatic shoulders increasing gradually for each age group. This was true for both dominant and non-dominant shoulders (Cashiers: dominant $-\mathrm{Chi}^{2}=18.41, \mathrm{p}=0.005$; non dominant $-\mathrm{Chi}^{2}=15.305, \mathrm{p}=0.018$, and for the control group: dominant $-\mathrm{Chi}^{2}=25.457, \mathrm{p}<0.001$; non dominant $\left.\mathrm{Chi}^{2}=28.139, \mathrm{p}<0.001\right)$.

Table 1. Anthropometric data of the study and control groups

\begin{tabular}{lcccc}
\hline \multicolumn{1}{c}{ Parameter } & $\begin{array}{c}\text { Cashiers } \\
(\mathrm{N}=196) \\
(\mathrm{M} \pm \mathrm{SD})\end{array}$ & $\begin{array}{c}\text { Control } \\
(\mathrm{N}=302) \\
(\mathrm{M} \pm \mathrm{SD})\end{array}$ & $\mathrm{t}$ & $\mathrm{p}$ \\
\hline Age (years) & $37.39 \pm 7.35$ & $38.58 \pm 9.36$ & -1.577 & 0.115 \\
Height $(\mathrm{cm})$ & $163.52 \pm 6.52$ & $163.61 \pm 6.08$ & -0.169 & 0.866 \\
Weight $(\mathrm{kg})$ & $61.38 \pm 11.14$ & $62.14 \pm 12.03$ & -0.705 & 0.481 \\
Body mass index & $22.95 \pm 3.95$ & $23.19 \pm 4.22$ & -0.647 & 0.518 \\
\hline
\end{tabular}

M - mean; SD - standard deviation. 
Table 2. Reported presence of shoulder pain - dominant arm

\begin{tabular}{lcccc}
\hline \multicolumn{1}{c}{ Variable } & $\begin{array}{c}\text { Cashiers } \\
(\mathrm{N}=196) \\
{[\mathrm{n}(\%)]}\end{array}$ & $\begin{array}{c}\text { Control } \\
(\mathrm{N}=302) \\
{[\mathrm{n}(\%)]}\end{array}$ & OR & $95 \% \mathrm{CI}$ \\
\hline Significant pain present & $72(36.7)$ & $60(19.9)$ & $1.849^{*}$ & $1.381-2.475$ \\
Significant pain absent & $124(63.3)$ & $242(80.1)$ & $0.790^{*}$ & $0.700-0.891$ \\
\hline
\end{tabular}

OR - odds ratio; CI - confidence interval.

* Statistically significant.

Table 3. Reported presence of shoulder pain - non-dominant arm

\begin{tabular}{lcccc}
\hline \multicolumn{1}{c}{ Variable } & $\begin{array}{c}\text { Cashiers } \\
(\mathrm{N}=196)\end{array}$ & $\begin{array}{c}\text { Control } \\
(\mathrm{N}=302) \\
{[\mathrm{n}(\%)]}\end{array}$ & $\begin{array}{c}\text { OR } \\
{[\mathrm{n}(\%)]}\end{array}$ & \\
\hline Significant pain present & $54(27.6)$ & $38(12.6)$ & $2.190^{*}$ & $1.506-3.183$ \\
Significant pain absent & $142(72.4)$ & $264(87.4)$ & $0.829^{*}$ & $0.753-0.913$ \\
\hline
\end{tabular}

Abbreviations as in Table 2.

Table 4. Reported presence of shoulder pain by age group

\begin{tabular}{|c|c|c|c|c|}
\hline \multirow{2}{*}{$\begin{array}{l}\text { Age } \\
\text { (years) }\end{array}$} & \multicolumn{2}{|c|}{$\begin{array}{c}\text { Pain in dominant arm } \\
{[\mathrm{n}(\%)]}\end{array}$} & \multicolumn{2}{|c|}{$\begin{array}{c}\text { Pain in non-dominant arm } \\
{[\mathrm{n}(\%)]}\end{array}$} \\
\hline & no & yes & no & yes \\
\hline \multicolumn{5}{|l|}{ Cashiers } \\
\hline $20-25$ & $6(75.0)$ & $2(25.0)$ & $8(100.0)$ & $0(0.0)$ \\
\hline $26-30$ & $16(76.7)$ & $8(33.3)$ & $16(66.7)$ & $8(33.3)$ \\
\hline $31-35$ & $43(81.1)$ & $10(18.9)$ & $45(84.9)$ & $8(15.1)$ \\
\hline $36-40$ & $34(63.0)$ & $20(37.0)$ & $39(72.2)$ & $15(27.8)$ \\
\hline $41-45$ & $16(50.0)$ & $16(50.0)$ & $22(68.8)$ & $10(31.3)$ \\
\hline $46-50$ & $4(40.0)$ & $6(60.0)$ & $5(50.0)$ & $5(50.0)$ \\
\hline $51-55$ & $5(33.3)$ & $10(66.7)$ & $7(46.7)$ & $8(53.3)$ \\
\hline total & $124(63.3)$ & $72(36.7)$ & $142(72.4)$ & $54(27.6)$ \\
\hline \multicolumn{5}{|l|}{ Control } \\
\hline $20-25$ & $27(100.0)$ & $0(0.0)$ & $26(96.3)$ & $1(3.7)$ \\
\hline $26-30$ & 35 (89.7) & $4(10.3)$ & $38(97.4)$ & $1(2.6)$ \\
\hline $31-35$ & $43(82.7)$ & $9(17.3)$ & 49 (94.2) & $3(5.8)$ \\
\hline $36-40$ & $48(87.3)$ & $7(12.7)$ & $50(90.9)$ & $5(9.1)$ \\
\hline $41-45$ & $35(77.8)$ & $10(22.2)$ & $32(71.1)$ & $13(28.9)$ \\
\hline $46-50$ & $27(69.2)$ & $12(30.8)$ & $36(92.3)$ & $3(7.7)$ \\
\hline $51-55$ & $27(60.0)$ & $18(40.0)$ & $33(73.3)$ & $12(26.7)$ \\
\hline total & $242(80.1)$ & 60 (19.9) & $264(87.4)$ & $38(12.6)$ \\
\hline
\end{tabular}




\section{Ultrasound/MRI examination}

The prevalence of abnormalities in the imaging examinations was almost equal between the 2 groups, with $8.7 \%$ (17 subjects - of whom 3 subjects bilaterally) showing alterations in the cashiers group, as opposed to $8.6 \%$ (26 subjects - of whom 14 subjects bilaterally) in the control group, although there was a significantly higher ratio of subjects with bilateral abnormalities in the controls $(\mathrm{OR}=5.444 ; 95 \% \mathrm{CI}: 1.257-23.587)$. The ultrasound results by arm dominance are given in Table 5 . Thirteen subjects whose US examinations were inconclusive were referred for MRI examination (5 in the cashiers group and 8 in the controls).

\section{Correlation of the imaging findings with age}

The prevalence of abnormalities showed a tendency to increase along with age in the control group for both shoulders, and in the dominant shoulder in the cashiers group (Table 6).

Table 5. Findings of the imaging - dominant and non-dominant shoulders

\begin{tabular}{lcccc}
\hline \multirow{2}{*}{ Group } & \multicolumn{2}{c}{ Dominant shoulder } & \multicolumn{2}{c}{ Non-dominant shoulder } \\
\cline { 2 - 5 } & $\begin{array}{c}\text { abnormal findings } \\
{[\mathrm{n}(\%)]}\end{array}$ & $\begin{array}{c}\text { normal findings } \\
{[\mathrm{n}(\%)]}\end{array}$ & $\begin{array}{c}\text { abnormal findings } \\
{[\mathrm{n}(\%)]}\end{array}$ & $\begin{array}{c}\text { normal findings } \\
{[\mathrm{n}(\%)]}\end{array}$ \\
\hline Cashiers & $6.1(12)$ & $93.9(184)$ & $4.1(8)$ & $95.9(188)$ \\
Control & $7.3(22)$ & $92.7(280)$ & $6.0(18)$ & $94.0(284)$ \\
\hline
\end{tabular}

Table 6. Findings of the imaging by age group

\begin{tabular}{|c|c|c|c|c|}
\hline \multirow{2}{*}{$\begin{array}{c}\text { Age } \\
\text { (years) }\end{array}$} & \multicolumn{2}{|c|}{ Dominant shoulder } & \multicolumn{2}{|c|}{ Non-dominant shoulder } \\
\hline & $\begin{array}{c}\text { normal findings } \\
{[\mathrm{n}(\%)]}\end{array}$ & $\begin{array}{c}\text { abnormal findings } \\
{[\mathrm{n}(\%)]}\end{array}$ & $\begin{array}{c}\text { normal findings } \\
{[\mathrm{n}(\%)]}\end{array}$ & $\begin{array}{c}\text { abnormal findings } \\
{[\mathrm{n}(\%)]}\end{array}$ \\
\hline \multicolumn{5}{|l|}{ Cashiers } \\
\hline $20-25$ & $8(100.0)$ & $0(0.0)$ & $8(100.0)$ & $0(0.0)$ \\
\hline $26-30$ & $21(87.5)$ & $3(12.5)$ & $23(95.8)$ & $1(4.2)$ \\
\hline $31-35$ & $51(96.2)$ & $2(3.8)$ & $52(98.1)$ & $1(1.9)$ \\
\hline $36-40$ & $53(98.1)$ & $1(1.9)$ & $50(92.6)$ & $4(7.4)$ \\
\hline $41-45$ & $31(96.9)$ & $1(3.1)$ & $30(93.8)$ & $2(6.3)$ \\
\hline $46-50$ & $8(80.0)$ & $2(20.0)$ & $10(100.0)$ & $0(0.0)$ \\
\hline $51-55$ & $12(80.0)$ & $3(20.0)$ & $15(100.0)$ & $0(0.0)$ \\
\hline total & $184(93.9)$ & $12(6.1)$ & $188(95.9)$ & $8(4.1)$ \\
\hline \multicolumn{5}{|l|}{ Control } \\
\hline $20-25$ & $27(100.0)$ & $0(0.0)$ & $27(100.0)$ & $0(0.0)$ \\
\hline $26-30$ & $37(94.9)$ & $2(5.1)$ & $39(100.0)$ & $0(0.0)$ \\
\hline $31-35$ & $50(96.2)$ & $2(3.8)$ & $51(98.1)$ & $1(1.9)$ \\
\hline $36-40$ & $53(96.4)$ & $2(3.6)$ & $54(98.2)$ & $1(1.8)$ \\
\hline $41-45$ & $44(97.8)$ & $1(2.2)$ & $44(97.8)$ & $1(2.2)$ \\
\hline $46-50$ & $32(82.1)$ & $7(17.9)$ & $34(87.2)$ & $5(12.8)$ \\
\hline $51-55$ & $37(82.2)$ & $8(17.8)$ & $35(77.8)$ & $10(22.2)$ \\
\hline total & $280(92.7)$ & $22(7.3)$ & $284(94.0)$ & $18(6.0)$ \\
\hline
\end{tabular}


Interestingly, there were no cashiers over 50 years of age with US abnormalities in the non-dominant shoulder.

Given the relatively small number of abnormalities within the 2 groups, we divided them into subgroups of over 50 and under 50 years of age. The prevalence of abnormalities increased along with age both in the cashiers (7.7\% in cashiers $<50$ years old, vs. $18.75 \% \geq 50$ years) and in the control group ( $6 \%$ in controls $<50$ years old, vs. $21.2 \% \geq 50$ years), with no statistically significant differences between the groups. The results for imaging abnormalities by arm dominance are shown in Tables 7 and 8 .

\section{Correlation of the questionnaire with imaging results}

Of the cashiers who had reported shoulder pain, $86.8 \%$ (79 subjects) had normal shoulders on imaging, as compared to $80.5 \%$ (62 subjects) in the control group. Conversely, approximately $5 \%$ of both the cashiers and controls had not reported pain and yet had abnormalities on US/MRI ( $4.8 \%$ cashiers; $4.9 \%$ controls). This means that of the cashiers with abnormal imaging findings, 70.5\% (12 subjects) were symptomatic (i.e., had reported pain), as compared to $57.7 \%$ (15 subjects) in the control group. The results for correlation between pain and imaging by arm dominance are presented in Tables 9 and 10 .

Table 7. Imaging findings - dominant shoulder

\begin{tabular}{|c|c|c|c|c|}
\hline \multirow{2}{*}{$\begin{array}{c}\text { Age } \\
\text { (years) }\end{array}$} & \multicolumn{2}{|c|}{$\begin{array}{l}\text { Findings } \\
{[\mathrm{n}(\%)]}\end{array}$} & \multirow[t]{2}{*}{ OR } & \multirow[t]{2}{*}{$95 \% \mathrm{CI}$} \\
\hline & normal & abnormal & & \\
\hline \multicolumn{5}{|l|}{$<50$} \\
\hline cashiers & $171(95.0)$ & $9(5.0)$ & 0.887 & $0.375-2.097$ \\
\hline control & $236(94.4)$ & $14(5.6)$ & & \\
\hline \multicolumn{5}{|l|}{$\geq 50$} \\
\hline cashiers & $13(81.3)$ & $3(18.8)$ & 1.269 & $0.294-5.487$ \\
\hline control & 44 (84.6) & $8(15.4)$ & & \\
\hline
\end{tabular}

Abbreviations as in Table 2.

Table 8. Imaging findings - non-dominant shoulder

\begin{tabular}{|c|c|c|c|c|}
\hline \multirow{2}{*}{$\begin{array}{c}\text { Age } \\
\text { (years) }\end{array}$} & \multicolumn{2}{|c|}{$\begin{array}{l}\text { Findings } \\
{[\mathrm{n}(\%)]}\end{array}$} & \multirow{2}{*}{ OR } & \multirow{2}{*}{$95 \% \mathrm{CI}$} \\
\hline & normal & abnormal & & \\
\hline \multicolumn{5}{|l|}{$<50$} \\
\hline cashiers & $172(95.6)$ & $8(4.4)$ & 1.407 & $0.518-3.822$ \\
\hline control & $242(96.8)$ & $8(3.2)$ & & \\
\hline \multicolumn{5}{|l|}{$\geq 50$} \\
\hline cashiers & $16(100.0)$ & $0(0.0)$ & n.a. & n.a. \\
\hline control & $42(80.8)$ & 10 (19.2) & & \\
\hline
\end{tabular}

n.a. - not applicable. Other abbreviations as in Table 2. 
Table 9. Correlation of the pain questionnaire and imaging - dominant shoulder

\begin{tabular}{lrc}
\hline \multirow{2}{*}{ Pain } & \multicolumn{3}{c}{$\begin{array}{c}\text { Findings } \\
{[\mathrm{n}(\%)]}\end{array}$} \\
\cline { 2 - 3 } & normal & abnormal \\
\hline Cashiers & & \\
$\quad$ reported & $65(90.3)$ & $7(9.7)$ \\
$\quad$ not reported & $119(96.0)$ & $5(4.0)$ \\
Control & & \\
$\quad$ reported & $48(80.0)$ & $12(20.0)$ \\
$\quad$ not reported & $232(95.9)$ & $10(4.1)$ \\
\hline
\end{tabular}

Table 10. Correlation of the pain questionnaire and imaging - non-dominant shoulder

\begin{tabular}{lrc}
\hline \multirow{2}{*}{ Pain } & \multicolumn{3}{c}{$\begin{array}{c}\text { Findings } \\
{[\mathrm{n}(\%)]}\end{array}$} \\
\cline { 2 - 4 } & normal & abnormal \\
\hline Cashiers & & \\
$\quad$ reported & $49(90.7)$ & $5(9.3)$ \\
$\quad$ not reported & $139(97.9)$ & $3(2.1)$ \\
Control & & \\
$\quad$ reported & $30(79.0)$ & $8(21.0)$ \\
not reported & $254(96.2)$ & $10(3.8)$ \\
\hline
\end{tabular}

\section{DISCUSSION}

It is clear that the increase in the reported shoulder pain amongst workers in the developed world has a major medical and socio-economic impact. In the EU, approximately $23 \%$ of workers in the existing and prospective member countries reported neck and shoulder pains, with the range extending from $8.2 \%$ in Ireland to $53.5 \%$ in Finland [24]. Unfortunately, aetiology and pathogenesis of shoulder disorders remain controversial. Moreover, complex anatomical and functional structure of the shoulder joint complicates identification of the source of pain. Gender, ethnicity, temperament and genetic factors also contribute to individual variation in pain sensitivity, which is reflected by the large ranges of incidence and prevalence rates reported in the literature [36,37]. Differences in case definitions, types of sampling procedures, variety in response rates, and the type of measurement instruments used are also responsible for these large ranges. Such diversity in the reported prevalence rates may impair an accurate evaluation and understanding of the problem.

Amongst the various sources of disparity, gender appears to be a major determining factor. One of the various possible hypotheses to explain this apparent disparity is that female patients may be more prone to suffer from non-specific pain, for which psychological or psycho-social factors have been invoked $[30,38,39]$. The gender discrepancy for shoulder pain is amplified in the case of repetitive work, although it should be also considered that the typical occupations requesting repetitive tasks are jobs predominantly performed by women. Repetitive work has shown a higher theoretical risk of MSD and is frequently correlated with "negative" 
psycho-social factors $[1,40]$. As noted above, this could influence the prevalence of non-specific pain among these types of workers. In the literature there is a wide variation (between 24\% and 65\%) in the quantitative findings regarding the prevalence of shoulder complaints among the female population performing repetitive work [41-44]. Indeed, a variety of work sectors have been studied, which each involves extremely different, though repetitive, tasks: sewing machine operators, assembly workers, furniture upholsterers, supermarket workers, dental hygienists, hair stylists, cake decorators and clerical workers [45-51]. Although within the sector of supermarket cashiers the relationship between repetitive strain injuries in the upper limb and occupation has been postulated [40,42,52-55], there has been relatively little data that confirms or refutes this hypothesis. In all the studies on the various occupational sectors, there is little homogeneity in age, sex, cultural and social variables. Given this lack of homogeneity, it has been proposed that the occurrence of MSDs should be also assessed in the general population [30]. Indeed, there is still a great need for population-based studies on shoulder disorders with well-defined and objective diagnostic criteria.

Finally, there is often lack of clarity on case definitions. There is an emerging consensus on the viewpoint that differing definitions of shoulder pain substantially contribute to the wide range of prevalence rates reported $[1,6,7,9,56]$. Overall, it appears that there is no widely accepted standard for clinical pain assessment that would facilitate comparison of outcomes across the studies and drawing valid conclusions. In our study we attempted to adhere to the aforementioned criteria for more homogenous and objective studies, reducing the variables as much as possible, introducing an objective diagnostic tool (US/MR imaging) and enlarging the study to include the general population. To our knowledge, there is no similar study in the literature. Consequently, we examined 2 groups of the same age range and sex, living in the same geographic area. Although the control group was selected at random, there was no statistical difference in somatic features (i.e., body mass index, right/left hand dominance, age, etc.) with respect to the study group. Moreover, the study group consisted of employees who had performed the same repetitive job for a reasonably long period (average service was 11.49 years) thus, eliminating the variables present in several studies where workers performed different tasks.

Our questionnaire was based on the Nordic Musculoskeletal Questionnaire, which is considered to be a good instrument for screening patients as it is sensitive and repeatable [57-59]. Finally, an imaging examination conducted by an experienced musculoskeletal radiologist provided an objective benchmark with which to compare the reported shoulder pain [60]. We decided to use US as a reference standard due to its accuracy, tolerability and cost-effectiveness. Furthermore, it allows a dynamic evaluation, which is not possible with other imaging techniques $[61,62]$. It is important to note that in our study, the ultrasound examinations were performed using a $15 \mathrm{MHz}$ matrix array probe instead of the 5 to $12 \mathrm{MHz}$ conventional probe commonly used in other studies. This allowed better spatial resolution, and consequently, gave higher image quality, enabling the assessment of even very small alterations.

The questionnaire revealed a statistically significant difference in the prevalence of reported pain between the supermarket cashiers and the general population control group (46.4\% versus $25.5 \%$ ). These findings are similar to those reported in the literature: in an analysis from the Swedish Work Environment Authority [63], 46\% of the checkout operators reported shoulder pain compared to $36 \%$ of the general female working population, whereas Niedhammer et al. have reported the presence of shoulder pain ranging from 22.9 to $51.4 \%$ among supermarket cashiers [44].

We observed abnormalities on imaging in $8.7 \%$ of the cashier shoulders, with a higher prevalence on the 
dominant side (6.1\%). A similar prevalence of shoulder abnormalities was observed in the control group (8.6\%), with again a higher prevalence in the dominant shoulder $(7.3 \%)$. It is interesting to note that there was a statistically significant higher prevalence of bilateral abnormalities in the control group than in the cashiers (4.6\% vs. $1.5 \%)$. A possible explanation is that, due to the position of the till, there is more mechanical loading on the right shoulder of the cashiers, whereas the controls could feasibly be exposed to more equal loading on both shoulders in their daily activities. However, there was no statistical difference between the number of abnormalities observed in the right and left arms of the cashiers, so the nature of the cashiers' work does not seem to influence the presence of abnormalities in the shoulder structures.

Correlating subjective symptoms and abnormal radiographic findings, the prevalence of specific pain was $13.2 \%$ among the cashiers and $19.5 \%$ among the general population. Non-specific pain prevalence was higher among the cashiers $(86.8 \%)$ than in the control group $(80.5 \%)$. If we consider only the subjects who had abnormal findings on imaging, there was a larger number of symptomatic shoulders among the cashiers $(70.5 \%)$ than in the control group $(57.7 \%)$, with the dominant arm (slightly) more involved (58\% dominant, $42 \%$ non-dominant). As the aim of this study was to investigate the presence of abnormalities rather than to analyze the specific characteristics of the observed pathologies, we cannot assess whether or not this higher percentage of symptomatic abnormalities in the cashiers group is due to more severe or extensive anatomic alterations than those reported in the controls. Nevertheless, it may in part be explained by the frequently advocated multifactorial origin of shoulder pain, that includes not only the effects of mechanical load, but also the psycho-social work environment $[1,11,40]$.

Comparison of our findings with earlier research is difficult, as the association of questionnaires and radiographic examination has seldom been used previously. In the only directly comparable study, $19.5 \%$ of a cohort of 128 cashiers reported shoulder pain, and $100 \%$ of them showed abnormalities on ultrasound [55]. However, the number of subjects is relatively small, and there is no comparison with a general female population. Miranda et al. and WalkerBone et al. have estimated the prevalence of non-specific pain in general female adult populations comparing reported pain to clinical examination: the rates of non-specific pain were $13.7 \%$ and $2.5 \%$, respectively [7,30]. A possible explanation for these lower values for prevalence of non-specific pain may be the use of a clinical rather than a diagnostic imaging examination.

Our results are consistent with several studies that have reported an increase in shoulder disorders along with age [64-66]. Ageing has been shown to be associated with degenerative changes in tendons and articular cartilage, and with the development of periarticular calcifications. In both the cashiers and the general population the prevalence of pain increased along with age, with higher values observed in the cashiers group. Indeed, the higher prevalence of pain in older age is reflected in an increase in anomalous US findings in both groups. However, degenerative changes may not always cause pain: we observed that approximately $9.1 \%$ of all the subjects who were 50 years of age or older were asymptomatic whilst having anomalous US findings.

\section{CONCLUSIONS}

Our results confirm the existing data about a higher prevalence of subjective shoulder complaints among female workers performing repetitive task, compared to the general population. However, this difference was not matched by an equivalent variation in radiographically verified shoulder disorders between the 2 groups. Limb dominance does not seem to have a significant influence on the prevalence, whereas complaints and imaging abnormalities increase along with age. 
Although pain often accompanies abnormal imaging findings, the presence of shoulder imaging anomalies may not necessarily be correlated with the symptoms. Whether specific or non-specific, shoulder pain tends to be more frequent among workers, reinforcing the suspicion that the cause of repetitive work complaints should be sought also within the psycho-social work environment. Prospective, controlled cohort studies, based on good case-definitions, will hopefully provide information needed to quantify the real amount of repetitive work-related shoulder pain in terms of the prevalence, incidence and functional impairment, which are necessary prerequisites for adequate treatment and prevention.

\section{REFERENCES}

1. Punnett L, Wegman DH. Work-related musculoskeletal disorders: The epidemiologic evidence and the debate. J Electromyogr Kinesiol. 2004;14(1):13-23, http://dx.doi.org/10.1016/ j.jelekin.2003.09.015.

2. Baldwin ML. Reducing the costs of work-related musculoskeletal disorders: Targeting strategies to chronic disability cases. J Electromyogr Kinesiol. 2004;14(1):33-41, http:// dx.doi.org/10.1016/j.jelekin.2003.09.013.

3. Urwin M, Symmons D, Allison T, Brammah T, Busby H, Roxby M, et al. Estimating the burden of musculoskeletal disorders in the community: The comparative prevalence of symptoms at different anatomical sites, and the relation to social deprivation. Ann Rheum Dis. 1998;57:649-55, http:// dx.doi.org/10.1136/ard.57.11.649.

4. Picavet HS, Schouten JS. Musculoskeletal pain in the Netherlands: Prevalences, consequences and risk groups, the DMC(3)-study. Pain. 2003;102:167-78, http://dx.doi. org/10.1016/s0304-3959(02)00372-x.

5. Hill J, Lewis M, Papageorgiou AC, Dziedzic K, Croft P. Predicting persistent neck pain: A 1-year follow-up of a population cohort. Spine. 2004;29(15):1648-54, http://dx.doi. org/10.1097/01.BRS.0000132307.06321.3C.
6. Luime JJ, Koes BW, Hendriksen IJ, Burdorf A, Verhagen AP, Miedema HS, et al. Prevalence and incidence of shoulder pain in the general population; A systematic review. Scand J Rheumatol. 2004;33:73-81, http://dx.doi. org/10.1080/03009740310004667.

7. Walker-Bone K, Palmer KT, Reading I, Coggon D, Cooper C. Prevalence and impact of musculoskeletal disorders of the upper limb in the general population. Arthritis Rheum. 2004;51(4):642-51, http://dx.doi.org/10.1002/ art.20535.

8. Feleus A, Bierma-Zeinstra SM, Miedema HS, Bernsen RMD, Verhaar JAN, Koes BW. Incidence of nontraumatic complaints of arm, neck and shoulder in general practice. Man Ther. 2008;135:426-33, http://dx.doi.org/10. 1016/j.math.2007.05.010.

9. Palmer KT, Harris EC, Linaker C, Cooper C, Coggon D. Optimising case definitions of upper limb disorder for aetiological research and prevention - A review. Occup Environ Med. 2012;69(1):71-8, http://dx.doi.org/10.1136/ oemed-2011-100086.

10. Silverstein B, Welp E, Nelson N, Kalat J. Claims incidence of work-related disorders of the upper extremities: Washington State, 1987 through 1995. Am J Public Health. 1998;88: 1827-33, http://dx.doi.org/10.2105/AJPH.88.12.1827.

11. van der Windt DA, Thomas E, Pope D, de Winter AF, Macfarlane G, Bouter L, et al. Occupational risk factors for shoulder pain: A systematic review. Occup Environ Med. 2000;57(7): 433-42, http://dx.doi.org/10.1136/oem.57.7.433.

12. de Zwart BCH, Broersen JP, Frings-Dresen MH, van Dijk FJ. Musculoskeletal complaints in the Netherlands in relation to age, gender and physically demanding work. Int Arch Occup Environ Health. 1997;70(5):352-60, http:// dx.doi.org/10.1007/s004200050229.

13. Gerr F, Marcus M, Ensor C, Kleinbaum D, Cohen S, Edwards A, et al. A prospective study of computer users, I: Study design and incidence of musculoskeletal symptoms and disorders. Am J Ind Med. 2002;41(4):221-35, http://dx.doi.org/10.1002/ajim.10066. 
14. Hooftman WE, van Poppel MN, van der Beek AJ, Bongers PM, van Mechelen W. Gender differences in the relations between work-related physical and psychosocial risk factors and musculoskeletal complaints. Scand J Work Environ Health. 2004;30(4):261-78, http://dx.doi. org/10.5271/sjweh.794.

15. Hooftman WE, van der Beek AJ, Bongers PM, van Mechelen W. Is there a gender difference in the effect of work-related physical and psychosocial risk factors on musculoskeletal symptoms and related sickness absence? Scand J Work Environ Health. 2009;35(2):85-95, http:// dx.doi.org/10.5271/sjweh.1316.

16. Reis P, Moro A, Merino E, Vilagra J. Influence of gender on the prevalence of Rsi/WRULD in meat-packing plants. Work. 2012;41 Suppl 1:4323-9.

17. Linton SJ, Hellsing AL, Halldén K. A population-based study of spinal pain among 35-45-year-old individuals: Prevalence, sick leave, and health care use. Spine. 1998;23:1457-63, http://dx.doi.org/10.1097/00007632-199807010-00006.

18. Centers for Disease Control and Prevention. Prevalence of self-reported arthritis or chronic joint symptoms among adults - United States, 2001. MMWR Morb Mortal Wkly Rep. 2002;51(42):948-50.

19. Strazdins L, Bammer G. Women, work and musculoskeletal health. Soc Sci Med. 2004;58:997-1005, http://dx.doi.org/ 10.1016/S0277-9536(03)00260-0.

20. Badcock LJ, Lewis M, Hay EM, Croft PR. Consultation and the outcome of shoulder-neck pain: A cohort study in the population. J Rheumatol. 2003;30:2694-9.

21. Bot SD, van der Waal JM, Terwee CB, van der Windt DA, Schellevis FG, Bouter LM, et al. Incidence and prevalence of complaints of the neck and upper extremity in general practice. Ann Rheum Dis. 2005;64(1):118-23, http://dx.doi. org/10.1136/ard.2003.019349.

22. Mantyselka PT, Turunen JHO, Ahonen RS, Kumpusalo EA. Chronic pain and poor self-related health. JAMA. 2003;290(18):2435-42， http://dx.doi.org/10.1001/ jama.290.18.2435.
23. Hasselstrom J, Liu-Palmgren J, Rasjo-Wraak G. Prevalence of pain in general practice. Eur J Pain. 2002;6:375-85, http://dx.doi.org/10.1016/S1090-3801(02)00025-3.

24. European Agency for Safety and Health at Work. OSH in figures: Work-related musculoskeletal disorders in the EU Facts and figures 2010. European Risk Observatory Report [cited 2010 Feb 10]. Available from: https://osha.europa.eu/ en/publications/reports/TERO09009ENC.

25. Ashbury FD. Occupational repetitive strain injuries and gender in Ontario, 1986 to 1991. J Occup Environ Med.1995;37(4):479-85, http://dx.doi.org/10.1097/00043764199504000-00021.

26. Hall W, Morrow L. Repetition strain injury: An Australian epidemic of upper limb pain. Soc Sci Med. 1988;27(6): 645-9, http://dx.doi.org/10.1016/0277-9536(88)90013-5.

27. Greving K, Dorrestijn O, Winters JC, Groenhof F, van der Meer K, Stevens M, et al. Incidence, prevalence, and consultation rates of shoulder complaints in general practice. Scand J Rheumatol. 2012;41(2):150-5, http://dx.doi. org/10.3109/03009742.2011.605390.

28. Mehlum IS, Kjuus H, Veiersted KB, Wergeland E. Self-reported work-related health problems from the Oslo health study. Occup Med (Oxf). 2006;56:371-9, http://dx.doi.org/ 10.1093/occmed/kq1034.

29. Nygren A, Berglund A, von Koch M. Neck-and-shoulder pain, an increasing problem. Strategies for using insurance material to follow trends. Scand J Rehabil Med Suppl. 1995;32:107-12.

30. Miranda H, Viikari-Juntura E, Heistaro S, Heliövaara M, Riihimäki H. A population study on differences in the determinants of a specific shoulder disorder versus nonspecific shoulder pain without clinical findings. Am J Epidemiol. 2005;161(9):847-55, http://dx.doi.org/10.1093/aje/ kwi112.

31. Helliwell PS, Bennett RM, Littlejohn G, Muirden KD, Wigley RD. Towards epidemiological criteria for soft-tissue disorders of the arm. Occup Med (Lond). 2003;53:313-9, http://dx.doi.org/10.1093/occmed/kqg034. 
32. Helliwell PS. Diagnostic criteria for work-related upper limb disorders. Br J Rheumatol. 1996;35:1195-6, http://dx.doi.org/ 10.1093/rheumatology/35.12.1195.

33. Bonde JP, Mikkelsen S, Andersen JH, Fallentin N, Baelum J, Svendsen SW, et al. Understanding work related musculoskeletal pain: Does repetitive work cause stress symptoms? Occup Environ Med. 2005;62:41-8, http://dx. doi.org/10.1136/oem.2003.011296.

34. Kuorinka I, Jonsson B, Lilbom A, Vinterberg H, BieringSørensen F, Andersson G, et al. Standardized Nordic Questionnaire for the analysis of musculoskeletal symptoms. App Ergon. 1987;18:233-7, http://dx.doi.org/10.1016/0003-6870 (87)90010-X.

35. Beggs I. Shoulder ultrasound. Semin Ultrasound CT MR. 2011;32(2):101-13, http://dx.doi.org/10.1053/j.sult.2010. 10.003 .

36. van der Heijden GJ. Shoulder disorders: A state-ofthe-art review. Baillieres Best Pract Res Clin Rheumatol. 1999;13:287-309, http://dx.doi.org/10.1053/berh. 1999.0021.

37. Bjelle A. Epidemiology of shoulder problems. Baillieres Clin Rheumatol. 1989;3:437-51, http://dx.doi.org/10.1016/ S0950-3579(89)80003-2.

38. Ireland DC. Psychological and physical aspects of occupational arm pain. J Hand Surg. 1985;13(1):5-10, http://dx.doi. org/10.1016/0266-7681(88)90041-1.

39. Hadler NM. Illness in the workplace: The challenge of musculoskeletal symptoms. J Hand Surg. 1985;10(4):451-6, http://dx.doi.org/10.1016/S0363-5023(85)80065-4.

40. Lundberg U, Dohns IE, Melin B, Sandsjö L, Palmerud G, Kadefors R, et al. Psychophysiological stress responses, muscle tension, and neck and shoulder pain among supermarket cashiers. J Occup Health Psychol. 1999;4(3):245-55, http://dx.doi.org/10.1037/1076-8998.4.3.245.

41. Barbosa RE, Assunção AÁ, de Araújo TM. Musculoskeletal pain among healthcare workers: An exploratory study on gender differences. Am J Ind Med. 2013;56(10):1201-12, http://dx.doi.org/10.1002/ajim.22215.
42. Leclerc A, Chastang J, Niedhammer I, Landre M, Roquelaure Y. Incidence of shoulder pain in repetitive work. Occup Environ Med. 2004;61(1):39-44.

43. Pandy R. Prevalence of upper limb disorders among female librarians. Occup Med (Lond). 2013;63(6):432-4, http://dx.doi.org/10.1093/occmed/kqt080.

44. Niedhammer I, Landre MF, LeClerc A, Bourgeois F, Franchi P, Chastang JF, et al. Disorders related to work organization and other occupational factors among supermarket cashiers. Int J Occup Environ Health. 1998;4(3):168-78, http://dx.doi.org/10.1179/oeh.1998.4.3.168.

45. Guidotti TL. Occupational repetitive strain injury. Am Fam Physician. 1992;45(2):585-92.

46. Kaergaard A, Andersen JH. Musculoskeletal disorders of the neck and shoulders in female sewing machine operators: Prevalence, incidence, and prognosis. Occup Environ Med. 2000;57(8):528-34, http://dx.doi.org/10.1136/ oem.57.8.528.

47. Ohlsson K, Attwell R, Skerfving S. Self-reported symptoms in the neck and upper limbs of female assembly workers. Scand J Work Environ Health. 1989;15:75-80, http://dx.doi. org/10.5271/sjweh.1879.

48. Nicoletti S, Consonni D, Carino M, di Leone G, Trani G, Battevi N, et al. Upper limb work-related musculoskeletal disorders (UL-WMSDs): A retrospective cohort study in three large factories of the upholstered furniture industry. Med Lav. 2008;99(4):281-96.

49. Harber P, Bloswick D, Pena L, Beck J, Lee J, Baker D. The ergonomic challenge of repetitive motion with varying ergonomic stresses: Characterizing supermarket checking work. J Occup Med. 1992;34:518-28.

50. Shenkar O, Mann J, Shevach A, Ever-Hadani P, Weiss P. Prevalence and risk factors of upper extremity cumulative trauma disorders in dental hygienists. Work. 1998;11: 263-75, http://dx.doi.org/10.1016/S1051-9815(98)00043-6.

51. Brandt LPA, Andersen JH, Lassen CF, Kryger A, Overgaard E, Vilstrup I, et al. Neck and shoulder symptoms and disorders among Danish computer workers. Scand 
J Work Environ Health. 2004;30(5):399-409, http://dx.doi. org/10.5271/sjweh.828.

52. Lannersten L, Harms-Ringdahl K. Neck and shoulder muscle activity during work with different cash register systems. Ergonomics. 1990;33(1):49-65, http://dx.doi. org/10.1080/00140139008927093.

53. Baron SL, Habes D. Occupational musculoskeletal disorders among supermarket cashiers. Scand J Work Environ Health. 1992;18 Suppl 2:127-9.

54. Panzone I, Melosi A, Carra G, Rappazzo G, Innocenti A. Repetitive movement of the upper limbs: Results of exposure evaluation and clinical investigation in cash register operators in supermarkets. Med Lav. 1996;87(6):634-9.

55. di Pede C, Manuli G, Dini F, Pinelli, Turini ML, Mariani M, et al. [Cumulative Trauma Disorders (CTDs) in supermarket cashiers]. G Ital Med Lav Ergon. 2011;33(4):452-5. Italian.

56. van Rijn RM, Huisstede BMA, Koes BW, Burdorf A. Associations between work-related factors and specific disorders of the shoulder - A systematic review of the literature. Scand J Work Environ Health. 2010;36(3):189-201, http://dx.doi. org/10.5271/sjweh.2895.

57. Palmer K, Smith G, Kellingray S, Cooper C. Repeatability and validity of an upper limb and neck discomfort questionnaire: The utility of the standardized Nordic questionnaire. Occup Med (Lond). 1999;49:171-5, http://dx.doi. org/10.1093/occmed/49.3.171.

58. Dickinson CE, Campion K, Foster AF, Newman SJ, O'Rourke AMT, Thomas PG. Questionnaire development - An examination of the Nordic Musculoskeletal Questionnaire. Appl Ergon. 1992;23:197-201, http://dx.doi. org/10.1016/0003-6870(92)90225-K.

59. Descatha A, Roquelaure Y, Chastang JF, Evanoff B, Melchior M, Mariot C, et al. Validity of Nordic-style questionnaires in the surveillance of upper-limb work-related musculoskeletal disorders. Scand J Work Environ Health. 2007;33(1):58-65, http://dx.doi.org/10.5271/sjweh.1065.
60. Alavekios DA, Dionysian E, Sodl J, Contreras R, Cho Y, Yian EH. Longitudinal analysis of effects of operator experience on accuracy for ultrasound detection of supraspinatus tears. J Shoulder Elbow Surg. 2013;22(3):375-80, http://dx.doi.org/10.1016/j.jse.2012.09.017.

61. Shahabpour M, Kichouh M, Laridon E, Gielen JL, de Mey J. The effectiveness of diagnostic imaging methods for the assessment of soft tissue and articular disorders of the shoulder and elbow. Eur J Radiol. 2008;65(2):194-200, http://dx.doi.org/10.1016/j.ejrad.2007.11.012.

62. Naredo E, Aguado P, de Miguel E, Uson J, Mayordomo L, Gijon-Baños J, et al. Painful shoulder: Comparison of physical examination and ultrasonographic findings. Ann Rheum Dis. 2002;61(2):132-6, http://dx.doi.org/10.1136/ard.61.2.132.

63. The Swedish Work Environment Authority and SCB - Statistics Sweden. [Unilateral repetitive work. Safety and health conditions at work, pain, sick leave, rate of sickness absence. Information on education and training and the labor market] [Internet]. Stockholm: Statistiska Centralbyrån (SCB); 2003:4. [cited 2003 Aug 20]. Available from: http://www.av.se/dokument/statistik/rapporter/IAM2003_04.pdf. Swedish.

64. Linsell L, Dawson J, Zondervan K, Rose P, Randall T, Fitzpatrick R, et al. Prevalence and incidence of adults consulting for shoulder conditions in UK primary care; Patterns of diagnosis and referral. Rheumatology. 2006;45:215-21, http://dx.doi.org/10.1093/rheumatology/kei139.

65. Yamaguchi K, Ditsios K, Middleton WD, Hildebolt CF, Galatz LM, Teefey SA. The demographic and morphological features of rotator cuff disease. A comparison of asymptomatic and symptomatic shoulders. J Bone Joint Surg Am. 2006;88(8):1699-704, http://dx.doi.org/10.2106/JBJS.E.00835.

66. Yamamoto A, Takagishi K, Osawa T, Yanagawa T, Nakajima D, Shitara H, et al. Prevalence and risk factors of a rotator cuff tear in the general population. J Shoulder Elbow Surg. 2010;19(1):116-20, http://dx.doi.org/10.1016/ j.jse.2009.04.006.

This work is available in Open Access model and licensed under a Creative Commons Attribution-NonCommercial 3.0 Poland License - http://creativecommons.org/ licenses/by-nc/3.0/pl/deed.en. 